\title{
A Rare Case of Rectal Cancer With Endometrial Metastasis: A Case Report
}

\section{Nadir Görülen Endometriyum Metastazlı Rektum Kanseri: Olgu Sunumu}

\author{
Sinem Ipor ${ }^{1}$, Onur Esbah², Sinem Kantarcıŏglu Coşkun ${ }^{3}$ \\ ${ }^{1}$ Düzce Üniversitesi Tıp Fakültesi, İç Hastalıkları Ana Bilim Dalı, Düzce \\ ${ }^{2}$ Düzce Üniversitesi Tıp Fakültesi, Tıbbi Onkoloji Bilim Dalı, Düzce \\ ${ }^{3}$ Düzce Üniversitesi Tıp Fakültesi, Tıbbi Patoloji Ana Bilim Dalı, Düzce
}

Dergiye Ulaşma Tarihi: 15.10.2019 Dergiye Kabul Tarihi: 27.01.2020 Doi: 10.5505/aot.2020.55822

\section{ÖZET}

Giriş: Kolorektal kanser (KRK) insidans ve kansere bağlı mortalitede tüm dünyada 3. sırada yer almaktadır. Biz bu olgu ile literatürde nadir olan, endometriyum metastazlı rektum kanseri vakasını sunmayı amaçladık.

Olgu sunumu: 62 yaşında kadın hasta 2014 yılı Ekim ayında rektal kanama şikâyeti ile dış merkeze başvurduğunda yapılan kolonoskopisinde lümeni tama yakın dolduran ülserovejetan kitle tespit edilmiş ve biyopsi alınmıştı. Biyopsi patolojisi adenokarsinom ile uyumlu olarak raporlanmış ve hastaya rektum kanseri tanısı ile low anterior rezeksiyon ameliyatı yapılmıştı. Hastanın adjuvan tedavisi tamamlanmasının ardından takibinin devamı için devir alınmıştı. 3 ay aralıklarla takibi yapılan hastanın kontrol tomografilerinde akciğer nodüllerinde RECIST kriterlerine göre \%20'nin üzerinde boyut artışı görülmesinden dolayı pozitron emisyon tomografisi (PET/CT) çekildi. PET/CT de akciğerdeki noduler lezyonlarda ve uterus korpusu içerisinde hipermetabolik odaklar tespit edildi. Hastaya akciğer nodüllerinden ve endometriyumdan biyopsi yapıldı. Hastanın yapılan akciğer tru-cut biyopsisi ve endometriyum küretaj biyopsisi metastatik adenokarsinom ( gastrointestinal sistem-kolon ile uyumlu) olarak raporlandi.

Tartışma: KRK'lı hastaların yaklaşık \% 20'sinde tanı anında uzak metastaz mevcuttur. Genel olarak, KRK'lar bölgesel lenf nodlarına, karaciğere, akciğere ve daha az sıklıkla kemik, beyin ve periton boşluğuna metastaz yapar. Çoğunlukla düz kas dokusundan oluşan uterus, nadiren ekstragenital kanserlerin metastatik bölgesi olarak tanımlanmaktadır. KRK'ların ise endometriyum metastazı gelişen vakaları literatürde sınırlı sayıda mevcuttur. Biz bu vakayı hem nadir görülmesi hem de metastatik tümörler ile uterusun primer tümörlerinin ayırıcı tanısının önemli olması nedeni ile vurguladik.

Anahtar Kelimeler: kolorektal, kanser, metastaz, endometriyum, adenokarsinom, olgu sunumu

\begin{abstract}
Background: Colorectal cancer (CRC) is ranked third in the world in incidence and cancer-related mortality. In this case report, we aimed to present a case of rectum cancer with endometrial metastasis which is rare in the literatüre.

Case report: On October, 2014; a 62-year-old woman was admitted to outer clinic with a complaint of rectal bleeding. In the colonoscopy, an ulcerovegetan mass was detected and biopsied. Biopsy pathology was reported as adenocarcinoma and the patient underwent a low anterior resection due to diagnosis of rectal cancer. The adjuvant therapy of the patient was completed and the patient was transferred to our clinic for follow-up. After adjuvant therapy, PET/CT examination was performed due to the fact that the sizes of nodules showed $20 \%$ increase according to RECIST criteria by thoracic tomography performed three months intervals. In PET / CT, hipermetabolic foci were detected in nodular lesions in the lung and within the uterine corpus. The patient's lung tru-cut biopsy and biopsy of the endometrial cavity was reported adenocarcinoma.

Conclusion: Approximately $20 \%$ of patients with CRC have distant metastasis at the time of diagnosis. In general, CRCs metastasize to regional lymph nodes, liver, lung, and less frequently to the bone, brain, and peritoneal cavity. The uterus, which is mostly composed of smooth muscle tissue, is rarely described as the metastatic region of extragenital cancers. Endometrium metastases of CRCs are cases in a limited number in the literature. We emphasize this case because of its rarity and beacuse of importance of differatial diagnosis of primary and metastatic tumors of the uterus.
\end{abstract}

Keywords: colorectal, cancer, metastasis, case report, endometrium, adenocarcinoma 


\section{INTRODUCTION}

Colorectal cancer (CRC) is ranked third in the world in incidence and cancer-related mortality[1]. CRC is more common in men than in women[2]. Approximately 50$60 \%$ of patients with colorectal cancer develop metastasis[3]. Most common sites of metastases in CRC is liver, lung, bone and brain[1]. In this case report, we aimed to present a case of rectum cancer with endometrial metastasis which is rare in the literature.

\section{CASE REPORT}

A 62-year-old female patient admitted to another hospital in October 2014 with the compaints of rectal bleeding; colonoscopy revealed a tumoral mass at the 10 th $\mathrm{cm}$ of the rectum and biopsy was performed and patient was diagnosed with rectum adenocarcinoma. Although thoracic and abdominal tomography for staging showed nodular lesions with the largest size of $8 \mathrm{~mm}$ in both lungs, and metastasis of peritumoral lymph node, the patient underwent low anterior resection without planning for neoadjuvant treatment and pathology revealed a $\mathrm{pT} 3 \mathrm{~N} 1 \mathrm{~b}$ adenocarcinoma in the rectum, staged $3 \mathrm{~b}$ because of the fact that two of the dissected 11 lymph nodes were metastatic and the tumor was advanced into subseroza. Following chemoradiotherapy in combination with adjuvant 5-FU, chemotherapy with adjuvant folinic acid (400mg $/ \mathrm{m} 2$ ), oxaliplatin $(85 \mathrm{mg} / \mathrm{m} 2)$, 5-FU (15 $\mathrm{min} 400$ $\mathrm{mg} / \mathrm{m} 2$ slow infusion followed by $2400 \mathrm{mg} / \mathrm{m} 2$ $48 \mathrm{~h}$ infusion) (mFOLFOX6) was completed and the patient was transferred to our clinic for follow-up. Before the follow-up, thoracic tomography was performed for staging and multiple nodules with the largest size of $5 \mathrm{~mm}$ were detected in the lung. PET/CT examination was performed due to the fact that the sizes of nodules showed 20\% increase according to RECIST criteria by thoracic tomography performed three months intervals. PET/CT revealed hipermetabolic foci in multipl nodular lesions in the lung and within the uterine corpus. Biopsy was performed from the lung nodules and endometrium. The patient's lung tru-cut biopsy and the curettage biopsy of the endometrial cavity were reported as metastatic adenocarcinoma (suggesting gastrointestinal system-colon origin). Histopathologically, the serial sections taken from all endometrial samples displayed cells with nuclei in the basal region which is generating gland formations showing cribriform structures, and normal endometrium tissue was dissappeared on the necrotic ground. In the lumens of the gland structures, dirty necrosis (wreath-like appearance) was noticed in some areas. Due to estrogen and progesterone receptor negativity (Figure 1-2) and CDX2 and CEA (Figure 3) positivity, it was primarily considered as metastasis of the colon, not as primary malignancy in the endometrium. Chemotherapy was planned because of the multiple metastases of the patient, K-ras and N-ras mutations were evaluated in order to plan the treatment for metastatic rectal cancer. The patient was K-ras and $\mathrm{N}$-ras wild type and mFOLFOX6 + Cetuximab treatment was initiated. Assessment of response in chemotherapy showed a partial responce to mFOLFOX6 + Cetuximab chemotherapy. Patient's treatment is still ongoing.
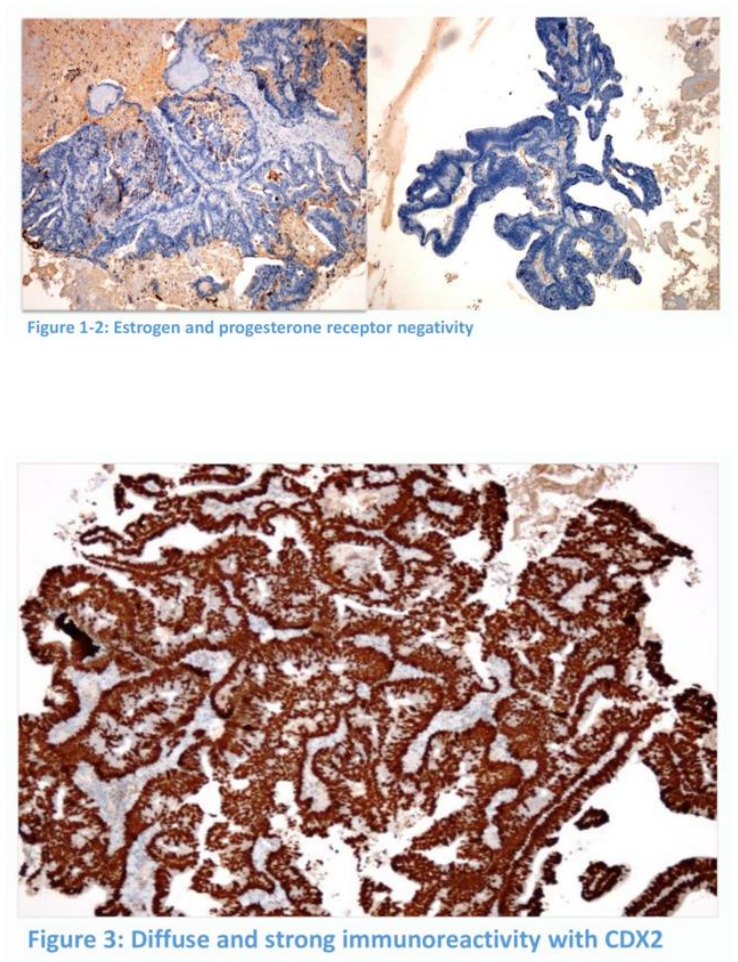

DISCUSSION 
Approximately $30 \%$ of CRCs originates from rectum[4]. Approximately $20 \%$ of patients with CRC have distant metastasis at the time of diagnosis[3]. In general, CRCs metastasize to regional lymph nodes, liver, lung, and less frequently to the bone, brain, and peritoneal cavity[5]. Hematogenously, proximal collector system of colon reaches the liver via the portal venous system[1]. After the liver, it reaches the lungs via cardiac route. The distal collecting system of the rectum bypasses the portal system, but instead enters the systemic circulation through the inferior and middle rectal veins and firstly reaches the lungs[6]. Therefore, rectal cancer makes thoracic organ metastasis more frequently than colon cancer[1]. CRCs can metastasize to the abdominal cavity and ovaries by neighborhood method via peritoneal fluid[1].

The uterus, which is mostly composed of smooth muscle tissue, is rarely described as the metastatic region of extragenital cancers[7]. Breast and gastrointestinal system tumors are the most common metastasis region of the uterus[7]. The most common site of metastasis in the uterine corpus is myometrium, but endometrial metastasis alone is rare[8]. Symptoms may vary depending on the anatomic metastasis site. Endometrial involvement usually presents with abnormal uterine bleeding, while myometrial involvement may be completely asymptomatic[8].

Secondary tumors of the uterine corpus are divided into two major groups as genital and extragenital organ metastases. Although neighboring organ neoplasms such as cervix, Fallopian tubes, ovaries, bladder and rectum are mostly spread by direct invasion, they can also metastasize to uterine corpus via lymphatics and blood vessels. The primary tumor of any extragenital organ may have a uterine metastasis from the hematogenous or lymphatic route, but this is extremely rare. Breast lobular carcinoma, signet-ring cell carcinoma of stomach and colonic carcinoma are the most commonly reported extragenital primary tumors which metastatsizes to the uterus[9]. Kumar et al. reported that $17,5 \%$ of the 63 extragenital neoplasia metastasized to uterine corpus, were colon origin[10]. In another study consisting of 11 cases compiling uterine metastases of extrapelvic primary tumors, 2

Adress for correspondence: Duzce Universitesi Egitim Ve Arastirma Hastanesi Düzce - Türkiye e-mail: sinemcess@gmail.com

Available at www.actaoncologicaturcica.com

Copyright $\odot$ Ankara Onkoloji Hastanesi patients were reported to have colon origin and the majority of cases had previously known malignancy[10]. Primary endometrial carcinoma and metastatic adenocarcinoma are similar in terms of tumor morphology. If there is an unusual pattern for primary endometrial carcinoma, if there is no pre-malignant change in endometrial glands, if there is a disproportionate invasion of serosa and myometrium; it should warn us. Because it can be metastatic carcinoma, and this should be considered in the differential diagnosis[9]. Due to histomorphological similarity, immunohistochemical panels are now considered the gold standard for the diagnosis of endometrial cancer[11]. Also in our case, it supported metastasis of a colon tumor because there was no positivity in estrogen and progesterone receptor with immunohistochemical staining and there was CDX2 and CEA positivity.

As a result, the uterus is rarely the metastasis site of the extragenital organs, and also endometrial metastasis alone is rare. Therefore, the distinction of primary tumors from metastatic tumors is quite important. Endometrium metastases of CRCs are cases in a limited number in the literature. We emphasize this case because of its rarity and beacuse of importance of differatial diagnosis of primary and metastatic tumors of the uterus.

\section{REFERENCES}

1. Riihimaki, M., et al., Patterns of metastasis in colon and rectal cancer. Sci Rep, 2016. 6: p. 29765.

2. Brenner, H., et al., Gender differences in colorectal cancer: implications for age at initiation of screening. Br J Cancer, 2007. 96(5): p. 828-31.

3. Christensen, T.D., et al., Systematic review: Incidence, risk factors, survival and treatment of bone metastases from colorectal cancer. J Bone Oncol, 2018. 13: p. 97-105.

4. Gaertner, W.B., et al., Rectal cancer: An evidence-based update for primary care providers. World J Gastroenterol, 2015. 21(25): p. 7659-71.

5. Zannoni, G.F., et al., Colonic carcinoma metastatic to the endometrium: the importance of clinical history in averting misdiagnosis as a primary endometrial carcinoma. Int J Surg Pathol, 2011. 19(6): p. 787-90.

6. Robinson, J.R., et al., Stage IV colorectal cancer primary site and patterns of distant metastasis. Cancer Epidemiol, 2017. 48: p. 92-95. 
7. Wang, J.H., et al., Papillary thyroid carcinoma with massive metastasis in the uterine corpus: a case report. BMC Cancer, 2013. 13: p. 551.

8. Mahendran, R. and K. Padmanaban, An interesting case of uterine tumour: a case report. International Journal of Reproduction, Contraception, Obstetrics and Gynecology, 2016: p. 4503-4505.

9. Kurman, R.J., International Agency for Research on Cancer., and World Health Organization., WHO classification of tumours of female reproductive organs. 4th ed. World Health Organization classification of tumours. 2014, Lyon: International Agency for Research on Cancer. 307 p.
10. Kumar, N.B. and W.R. Hart, Metastases to the uterine corpus from extragenital cancers. A clinicopathologic study of 63 cases. Cancer, 1982. 50(10): p. 2163-9.

11. Colling, R., et al., Endometrial metastasis of colorectal cancer with coincident endometrial adenocarcinoma. BMJ Case Rep, 2010. 2010. 